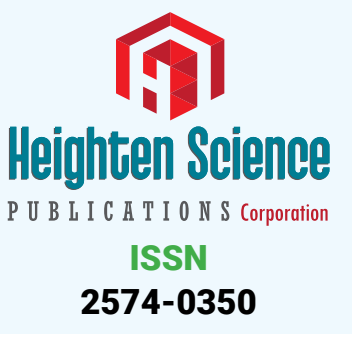

*Address for Correspondence: Dashkhuu Khasbaatar, Laboratory of Inorganic Chemistry, Institute of Chemistry and Chemical Technology of Mongolian Academy of Science, Peace Avenue, Ulaanbaatar 13330, Mongolia, Tel. +976-75754400-1198; E-mail: d_khasbaatar@ seas.num.edu.mn

Submitted: 21 December 2016

Approved: 09 January 2017

Published: 11 January 2017

Copyright: @ 2017 Otgonjargal E, et al. This is an open access article distributed under the Creative Commons Attribution License which permits unrestricted use, distribution, and reproduction in any medium, provided the original work is properly cited

Keywords: Layered double hydroxide; Thermal treatment; Adsorption; Chromium

\title{
Removal of Chromium from Aqueous Solution by Thermally Treated Mgal Layered Double Hydroxide
}

\author{
Enkhtur Otgonjargal1', Byambasuren Nyamsuren', Enkhtuul \\ Surenjav ${ }^{1}$, Gunchin Burmaa ${ }^{1}$, Jadambaa Temuujin ${ }^{2}$ and \\ Dashkhuu Khasbaatar ${ }^{1,3 *}$ \\ 'Laboratory of Inorganic Chemistry, Institute of Chemistry and Chemical Technology of \\ Mongolian Academy of Science, Peace Avenue, Ulaanbaatar 13330, Mongolia \\ ${ }^{2}$ Laboratory of Materials Science and Technology, Institute of Chemistry and Chemical \\ Technology of Mongolian Academy of Science, Peace Avenue, Ulaanbaatar 13330, Mongolia \\ ${ }^{3}$ Department of Chemical and Biological Engineering, School of Engineering and Applied \\ Sciences, National University of Mongolia, P.O.Box 46A/257, Ulaanbaatar, Mongolia
}

\section{ABSTRACT}

MgAl based layered double hydroxide (MgAl-LDH) was used as adsorbent for the removal of chromium oxyanion from an aqueous solution. MgAl-LDH was synthesized successfully using coprecipitation method, and was characterized by X-Ray Diffractometer (XRD), Scanning electron microscopy with energy dispersive X-ray spectroscopy (SEM-EDX). MgAl-LDH was thermally treated for improving the chromium adsorption. Samples were treated at $220^{\circ} \mathrm{C}$ and $450^{\circ} \mathrm{C}$. A negligible difference of total chromium adsorption capacities was observed between MgAl$\mathrm{LDH}_{000}$ and $\mathrm{MgAl}-\mathrm{LDH}_{220}$ as $12.56 \mathrm{mg} / \mathrm{g}$ and $11.01 \mathrm{mg} / \mathrm{g}$. The maximum chromium adsorption capacity of MgAl-LDH was $88.07 \mathrm{mg} / \mathrm{g}$ at $500 \mathrm{~g} / \mathrm{l}$ chromium concentration for MgAl-LDH which has been thermally treated at $450^{\circ} \mathrm{C}\left(\mathrm{MgAl}^{\left.-\mathrm{LDH}_{450}\right)}\right)$. The results indicated that memory effects of thermally treated MgAl-LDH at certain temperatures were retained and enhanced chromium removal efficiency.

\section{INTRODUCTION}

One of the most toxic heavy metals contaminants of concern is the hexavalent chromium (Cr) in drinking water due to natural and anthropogenic activity. Chromium contamination is present in the effluents produced during the electroplating, leather tanning, cement, mining, dyeing and photography industries [1,2].

According to the World Health Organization (WHO) guidelines, the maximum concentration limitation for $\mathrm{Cr}$ is $0.05 \mathrm{mg} / \mathrm{L}$ in drinking water [3]. $\mathrm{Cr}$ (VI) is highly mobile and is considered acutely as toxic and mutagenic for most organisms; in humans its main effects are on skin, liver, kidney and respiratory organs, resulting in a variety of diseases such as dermatitis, hepatic and renal tubular necrosis, bronchitis and bronchogenic carcinoma [4]. Moreover, hexavalent chromium is more toxic than trivalent chromium. This is due to easy reduction, liability, movability and entry into the cell via surface uptake pathway of hexavalent chromium. On the other hand, trivalent chromium is inert and undergoes precipitation in biological $\mathrm{pH}$ resulting nontoxicity of trivalent chromium $[5,6]$. 
Recently developed layered double hydroxides (LDHs), known as hydrotalcite-like compounds, are a class of synthetic two dimensional nanostructured anionic clays whose structure can be closely related to that of brucite, $\mathrm{Mg}(\mathrm{OH})_{2}$ [7]. Layered double hydroxide can be represented by the general formula $\left[\mathrm{M}^{2+}{ }_{1-\mathrm{x}} \mathrm{M}^{3+}{ }_{\mathrm{x}}(\mathrm{OH})_{2}\right]^{\mathrm{x+}}\left(\mathrm{A}^{\mathrm{n}}\right)_{\mathrm{x} / \mathrm{n}} \mathrm{mH}_{2} \mathrm{O}$, where $\mathrm{M}^{2+}$ and $\mathrm{M}^{3+}$ are divalent and trivalent cations, respectively; $\mathrm{x}$ is the $\mathrm{M}^{2+} / \mathrm{M}^{3+}$ molar ratio and $\mathrm{A}^{\mathrm{n}}$. is an anion. Because of unique physicochemical properties, rolling host of anionic species, and inexpensive, LDH can be used many applications such as sorbents, catalyst precursors, medicine stabilizers and ionic conductors. They have positively charged surface when it is in aqueous solution. Thus, negatively charged contaminants are easily adsorbed on them. Not only adsorption but also intercalation space can play dominant roll to trapping negatively charged anions [8]. Due to the exchangeability of the interlayer anions and the high charge density of the sheets, LDH has paid attention in several studies as sorbents to remove harmful anions such as arsenate [9], phosphate [10], and fluoride [11].

Thermal treatment as an efficient modification method is favorable to enhance surface defect of derivatives and beneficial for inner reaction. Calcinated LDHs (layered double oxide, defined as LDO) under a certain temperature can maintain "memory effect" in aqueous solutions [12].

In this study, MgAl layered double hydroxide (MgAl-LDH) was thermally treated at $220^{\circ} \mathrm{C}$ and $450^{\circ} \mathrm{C}$. These two temperatures were main alteration of structure of $\mathrm{MgAl}-\mathrm{LDH}$. Thus, three types of $\mathrm{LDH}$ including uncalcined MgAl-LDH, calcined at $220^{\circ} \mathrm{C}$ and $450^{\circ} \mathrm{C}$ were selected to study on adsorption of chromium from aqueous solution. Therefore, we investigated what kind of change would be happened especially structure of the three sorbents after adsorption of chromium on the sorbents.

\section{MATERIALS AND METHODS}

\section{Materials}

Magnesium chloride hexahydrate $\left(\mathrm{MgCl}_{2} \cdot 6 \mathrm{H}_{2} \mathrm{O}\right)$, Aluminum chloride hexahydrate $\left(\mathrm{AlCl}_{3} \cdot 6 \mathrm{H}_{2} \mathrm{O}\right)$, sodium hydroxide $(\mathrm{NaOH})$, sodium carbonite $\left(\mathrm{Na}_{2} \mathrm{CO}_{3}\right)$ and sodium dichromate dihydrate $\left(\mathrm{Na}_{2} \mathrm{Cr}_{2} \mathrm{O}_{7} \cdot 2 \mathrm{H}_{2} \mathrm{O}\right)$ with analytical grade were used for the synthesis of the LDH and were purchased from Sigma Aldrich Co., Ltd, and used without further purification. Deionized water was used throughout the synthesis and treatment processes

\section{Synthesis of the MgAI-LDH and Thermal treatment}

MgAl-LDH adsorbent was synthesized using traditional co-precipitation method [13]. In a typical procedure, $24.1 \mathrm{~g}$ of $\mathrm{MgCl}_{2} \cdot 6 \mathrm{H}_{2} \mathrm{O}(0.198 \mathrm{M})$ and $9.6 \mathrm{~g} \mathrm{of} \mathrm{AlCl}_{3} \cdot 6 \mathrm{H}_{2} \mathrm{O}$ $(0.0662 \mathrm{M})$ were dissolved in $600 \mathrm{~cm}^{3}$ distilled water (Solution 1). Solution 2 was prepared by dissolving $31.8 \mathrm{~g}$ of $\mathrm{Na}_{2} \mathrm{CO}_{3}(0.3 \mathrm{M})$ in $400 \mathrm{~cm}^{3}$ distilled water. Solution 1 and 2 was added into $1 \mathrm{~L}$ distilled water under constant stirring at a temperature of $25^{\circ} \mathrm{C}$ (at ambient temperature), then the $\mathrm{pH}$ of the mixed solution was kept at 10 by adding $1 \mathrm{M} \mathrm{NaOH}$. The mixture was aged at $60^{\circ} \mathrm{C}$ for $4 \mathrm{~h}$. Then the precipitate was separated by a filter paper and washed with distilled water. The wet solid was dried at $50^{\circ} \mathrm{C}$ for $24 \mathrm{~h}$ to obtain the MgAl-LDH. The thermal treatment of MgAl-LDH was carried out in an oven at $220^{\circ} \mathrm{C}$ and $450^{\circ} \mathrm{C}$ temperatures for 4 hours in air. $10 \mathrm{~g}$ of the MgAl-LDH was taken for thermal treatment. After thermal treatment, mass losses of the $\mathrm{MgAl}-\mathrm{LDH}$ at $220^{\circ} \mathrm{C}$ and $450^{\circ} \mathrm{C}$ were $18 \%$ and $37.5 \%$, respectively.

\section{Adsorption Experiments}

Stock solution of $\mathrm{Cr}(\mathrm{VI})$ was prepared by dissolving $\mathrm{Na}_{2} \mathrm{Cr}_{2} \mathrm{O}_{7} \cdot 2 \mathrm{H}_{2} \mathrm{O}$ in deionized water. Adsorption kinetics for removing chromium was studied at the time range from 0.5 minutes to 1440 minutes with constant concentration of chromium at $100 \mathrm{mg} / \mathrm{l}$ 
for MgAl-LDH with no-thermal treatment $\left(\mathrm{MgAl}_{-} \mathrm{LDH}_{000}\right)$ and MgAl-LDH with thermal treatment at $220^{\circ} \mathrm{C}\left(\mathrm{MgAl}_{-} \mathrm{LDH}_{220}\right)$. For MgAl-LDH with thermal treatment at $450^{\circ} \mathrm{C}$ $\left(\mathrm{MgAl}-\mathrm{LDH}_{450}\right)$ was used chromium concentration of $500 \mathrm{mg} / \mathrm{l}$. All experiments were performed under constant stirring of $200 \mathrm{rpm}$. Adsorption isotherms were conducted at $25^{\circ} \mathrm{C}$ with the initial $\mathrm{pH}$ of 7.0 , and the adsorbent dose was kept as $5 \mathrm{~g} / \mathrm{l}$. The $\mathrm{pH}$ of solution was adjusted to the desired values by adding a little amount of $\mathrm{HCl}$, and $\mathrm{NaOH}$ solutions with $0.1 \mathrm{~N}$ concentration.

\section{Measurements}

X-ray diffraction patterns were recorded using $\mathrm{CuK} \alpha$ radiation $(\mathrm{n}=1.5418 \AA \hat{)}$ on a Philips PW1800 diffractometer operating at $40 \mathrm{kV}$ and $40 \mathrm{~mA}$ with $0.25^{\circ}$ divergence slit, $0.5^{\circ}$ anti-scatter slit, between 1.5 and $20^{\circ}(2 \theta)$ at a step size of $0.0167^{\circ}$. A scanning electron microscope (SEM, S-3400 N, Hitachi,Tokyo, Japan) equipped with energy dispersive X-ray (EDX) was used. $\mathrm{pH}$ values were measured with digital $\mathrm{pH}$ meter (pH300, Hanna Instruments, Italy). Thermogravimetric and differential thermal analyses (TGA and DTA) were carried out using a TG/DTA7300 (Hitachi Exstar) at the temperature range of $25-970^{\circ} \mathrm{C}$ with heating rate of $5^{\circ} \mathrm{C} / \mathrm{min}$ in air flow $(100$ $\mathrm{cm}^{3} / \mathrm{min}$ ). Chromium concentrations in the solution were determined by UV-Visible spectrophotometry method at $450 \mathrm{~nm}$. BH-1200 muffle furnace was used to thermal treatment of the MgAl-LDH.

\section{RESULTS AND DISCUSSION}

\section{Characterization of the MgAl-LDH}

XRD of MgAl- $\mathrm{LDH}_{\text {ooo }}$ : Synthesized MgAl-LDH was characterized with XRD which is shown in Figure 1. It shows three LDHs sharp and symmetric peaks at lower $2 \theta$ as (003) and (006), which are characteristic of a lamellar material.

SEM image SEM-EDX analysis: The morphologies of MgAl-LDH ${ }_{000}$ were characterized by SEM EDX. As shown in Figure 2, a typical hydrotalcite-like structure was exhibited and the orderliness was clearly. The $\mathrm{MgAl}-\mathrm{LDH}_{000}$ was observed as homogenously distributed nano particles with layered double structure. A distance between layered double structure was measured around 20-30 $\mathrm{nm}$. The ratio of metals is an important parameter for characterizing $\mathrm{MgAl}-\mathrm{LDH}_{000}$ compounds and the molar ratio of $\mathrm{Mg}$ to $\mathrm{Al}$ was 2.57 which is consistent with the initial ratio of $\mathrm{Mg} / \mathrm{Al}$.

DTA and TGA analysis of MgAl- $\mathrm{LDH}_{000^{\circ}}$ Figure 3 shows TGA and DTA pattern of MgAl$\mathrm{LDH}$. On the DTA curve, the first endothermic peak occurred at $182^{\circ} \mathrm{C}$ and it ceased at $223^{\circ} \mathrm{C}$. A sharp falling TGA curve up to $205^{\circ} \mathrm{C}$ represented loss of interlayer and

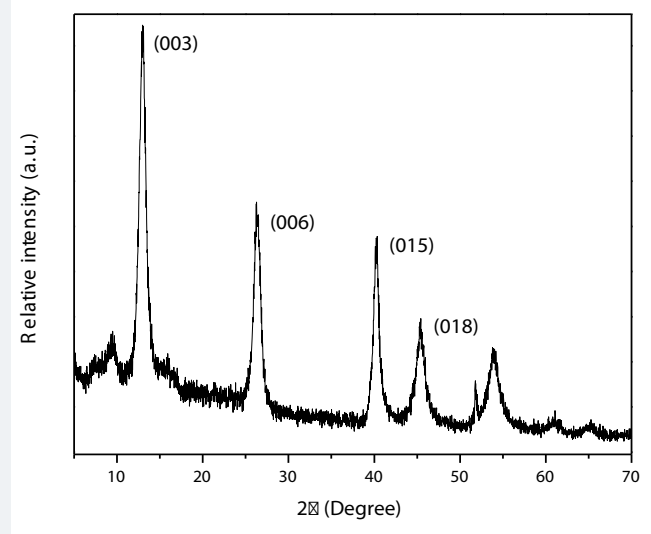

Figure 1: XRD pattern of MgAl-LDH 


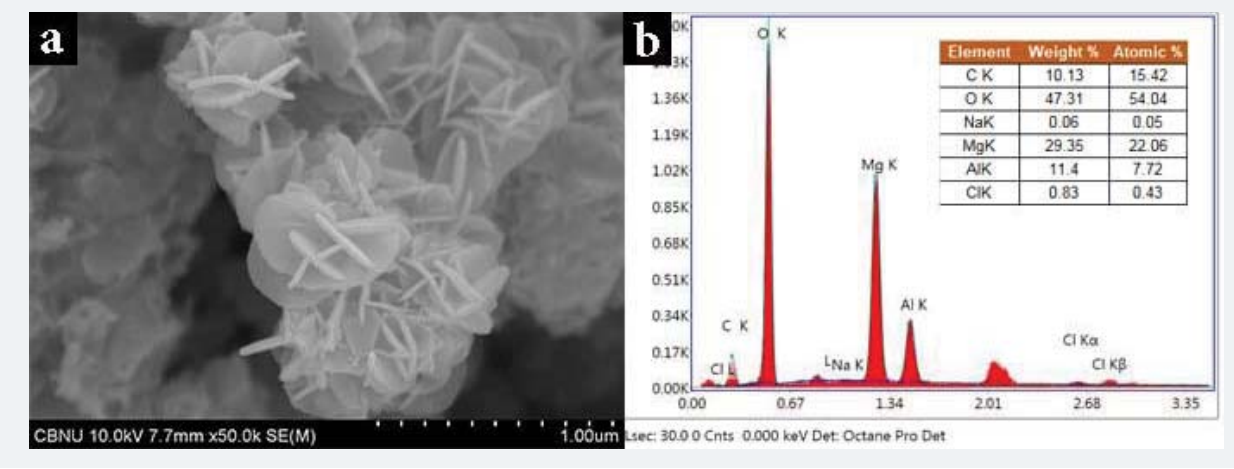

Figure 2: SEM image of (a) MgAl-LDH ${ }_{000}$ and (b) its EDX results.

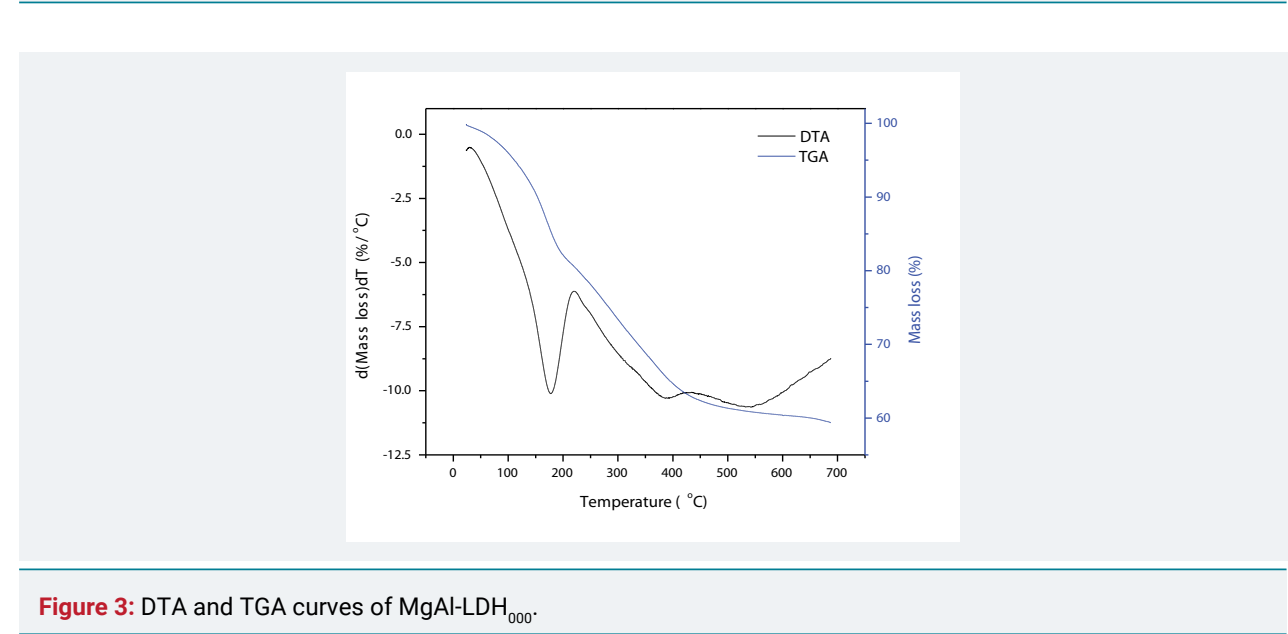

adsorbed water. The second endothermic process was occurred at $393^{\circ} \mathrm{C}$ and it ended at $440^{\circ} \mathrm{C}$. The slope of the TGA curve was decreased until $440^{\circ} \mathrm{C}$ after the endothermic process. The decomposition of interlayer hydroxyl and carbonate anions occurred at the range of $223-440^{\circ} \mathrm{C}[14,13]$. Thermal treatment is one of the favorable methods to enhance surface defect of derivatives and inner reaction. Thermally treated MgAl-LDH under specific temperature can retain "memory effect" in aqueous solutions. Moreover, $\mathrm{MgAl}-\mathrm{LDH}$ can be readily transferred to the conforming mixed oxide by heating to a certain temperatures which typically involve dehydration at $220^{\circ} \mathrm{C}$, dihydroxylation, and decomposition of anions at $450^{\circ} \mathrm{C}$ :

1. Dehydration $\left(100-220^{\circ} \mathrm{C}\right): \quad\left[\mathrm{M}^{2}{ }_{1-\mathrm{x}} \mathrm{M}_{\mathrm{x}}^{3}{ }_{\mathrm{x}}(\mathrm{OH})_{2}\right]^{\mathrm{x}+}\left(\mathrm{A}^{\mathrm{n}-}\right)_{\mathrm{x} / \mathrm{n}} \cdot \mathrm{mH}_{2} \mathrm{O} \rightarrow\left[\mathrm{M}_{1-\mathrm{x}}{ }^{2} \mathrm{M}_{\mathrm{x}}^{3}(\mathrm{OH})_{2}\right]$ ${ }^{\mathrm{x}}\left(\mathrm{A}^{\mathrm{n}}\right)_{\mathrm{x} / \mathrm{n}}$

2. Dehydroxylation $\left(350-450^{\circ} \mathrm{C}\right):\left[\mathrm{M}_{1-\mathrm{x}}^{2} \mathrm{M}_{\mathrm{x}}^{3}(\mathrm{OH})_{2}\right]^{\mathrm{x}+}\left(\mathrm{A}^{\mathrm{n}-}\right)_{\mathrm{x} / \mathrm{n}} \rightarrow\left[\mathrm{M}_{1-\mathrm{x}}^{2} \mathrm{M}_{\mathrm{x}}^{3} \mathrm{O}\right]^{\mathrm{x}+}\left(\mathrm{A}^{\mathrm{n}-}\right)_{\mathrm{x} / \mathrm{n}}$

3. Decomposition of anion $\left(420-450^{\circ} \mathrm{C}\right):\left[\mathrm{M}_{1-\mathrm{x}}^{2} \mathrm{M}_{\mathrm{x}}^{3} \mathrm{O}\right]^{\mathrm{x}+}\left(\mathrm{A}^{\mathrm{n}-}\right)_{\mathrm{x} / \mathrm{n}} \rightarrow \mathrm{M}_{1-\mathrm{x}}^{2} \mathrm{M}_{\mathrm{x}}^{3} \mathrm{O}_{1+\mathrm{x} / 2}\left(\mathrm{BO}_{\mathrm{y}}\right)$

Where $\mathrm{BO}_{\mathrm{y}}$ denotes the species of decomposed anion [15,7]. According to the DTA and TGA data, physico-chemical characteristics of MgAl-LDH were changed at $220^{\circ} \mathrm{C}$ and $450^{\circ} \mathrm{C}$ temperatures. Therefore, MgAl-LDH was thermally treated at $220^{\circ} \mathrm{C}$ and $450^{\circ} \mathrm{C}$.

XRD of MgAl-LDH ${ }_{000^{\prime}} M g A l-L D H$, and $M g A l-L D H_{450^{\circ}}$ The Figure 4 shows XRD patterns of the synthesized and thermally treated LDHs. The Figure $4 \mathrm{a}$ is the typical pattern of hydrotalcite-like pattern. In the case of MglAl- $\mathrm{LDH}_{220}$, considerable changes were observed for MglAl- $\mathrm{LDH}_{220}$ and MglAl- $\mathrm{LDH}_{450^{\circ}}$ An intensive and sharp reflection of the (003) planes at $12.9^{\circ} 2 \theta$ value for $\mathrm{MgAl}-\mathrm{LDH}_{000}$ shifted to $15.3^{\circ}$ for $\mathrm{MglAl}-\mathrm{LDH}_{220^{\circ}}$ On the other hand, a broad asymmetric reflection at higher $2 \theta$ value of $\mathrm{MgAl}-\mathrm{LDH}_{000}$ was disappeared for $\mathrm{MgAl}-\mathrm{LDH}_{220}$ due to heating up to $220^{\circ} \mathrm{C}$ and removal of interlayer 


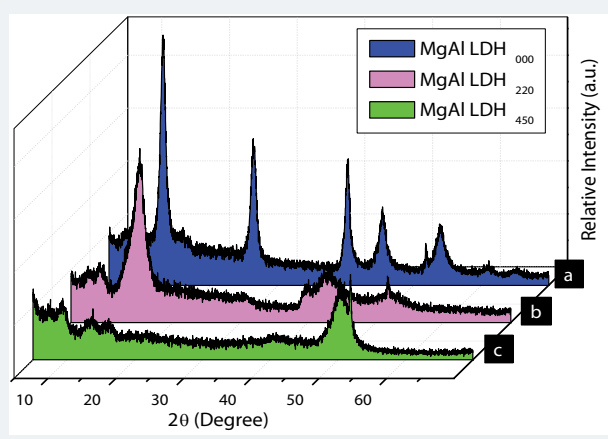

Figure 4: XRD patterns of MgAl-LDH ${ }_{000}(\mathrm{a}), \mathrm{MgAl}^{-\mathrm{LDH}_{220}}$ (b) and MgAl-LDH ${ }_{450}$ (c).

hydrides. For MglAl- $\mathrm{LDH}_{450}$, the well-defined diffraction peaks of the $\mathrm{MgAl}-\mathrm{LDH}_{000}$ were replaced by broad peaks, therefore representing a poor long-range ordered phase. A nanocrystalline material with very tiny nanoparticles or even an amorphous phase was corresponded to these broad peaks [12].

\section{Adsorption study of $\mathrm{Cr}$ (VI) on the $\mathrm{MgAl}^{-\mathrm{LDH}_{000}},{\mathrm{MgAl}-\mathrm{LDH}_{220}, \text { and MgAl-LDH }}_{450}$}

Influence of $\mathrm{pH}$ on Chromium uptake: Figure 5 shows the quantitative analysis of chromium adsorbed on the MgAl-LDH ${ }_{000}, \mathrm{MgAl}-\mathrm{LDH}_{220}$, and MgAl-LDH ${ }_{450}$ at increasing $\mathrm{pH}$ levels. The difference in the curves may be explained by the inherent chemical and physical properties of adsorbents. As the $\mathrm{pH}$ decreased, the adsorbent showed a more pronounced reactivity with chromium. In an acidic medium, the adsorbent was highly protonated and this characteristic increased the attracting effect of oxyanions due to the lack of negative charges. Chromium adsorption was found to be significantly influenced by the solution $\mathrm{pH}$. One gram of $\mathrm{MgAl}-\mathrm{LDH}_{450}$ at $\mathrm{pH} 5.0$ was adsorbed 108.7 $\mathrm{mg}$ of chromium in one $\mathrm{L}$ aqueous solution which represents the maximum adsorption. However, chromium adsorption of $\mathrm{MgAl}_{-} \mathrm{LDH}_{220}$ was less than that of $\mathrm{MgAl}-\mathrm{LDH}_{000}$. It could be explained that the shrinkage of gaps between sheets of $\mathrm{MgAl}$ oxide planes. The maximum adsorptions of MgAl- $\mathrm{LDH}_{000}$ and $\mathrm{MgAl}-\mathrm{LDH}_{220}$ at $\mathrm{pH} 3$ were $11.79 \mathrm{mg} / \mathrm{g}$ and $6.85 \mathrm{mg} / \mathrm{g}$, respectively. Adsorption capacity $\mathrm{MgAl}-\mathrm{LDH}_{450}$ was around 9 times higher than the value of $\mathrm{MgAl}-\mathrm{LDH}_{000}$. It was explained by the main anion exchange mechanism involved in the sorption of chromium on the adsorbent. MgAl-LDH can remove anions from solution by three different mechanisms such as adsorption on external surface, intercalation by anion exchange and intercalation by reconstruction of calcined material [16]. It meant to be that the crystal structure of $\mathrm{MgAl}^{-\mathrm{LDH}_{450}}$ was destructed to amorphous nano type material at $450^{\circ} \mathrm{C}$ and $\mathrm{MgAl}$ double oxide may be obtained. Reconstruction and recrystallization of $\mathrm{MgAl}^{-\mathrm{LDH}_{450}}$ was taken place due to the memory effect of LDH [7] when chromium adsorption was happened.

Figure 6 shows the adsorption kinetics of Chromium for an initial solution $\mathrm{pH}$ of 7.0 measured with the three adsorbents. It reveals that the adsorption rate sharply increased up to 360 minutes and then almost stabilized up to 700 minutes. Further, the equilibrium was occurred for $\mathrm{MgAl}-\mathrm{LDH}_{450}$. Adsorption rate for $\mathrm{MgAl}-\mathrm{LDH}_{220}$ and MgAl$\mathrm{LDH}_{000}$ increased in few seconds and reached to equilibrium. However, adsorption of the latter adsorbents was very low compared with $\mathrm{MgAl}-\mathrm{LDH}_{450}$.

Figure 7 shows adsorption capacities of three adsorbents when the concentration of chromium increases at $\mathrm{pH}$ 7. There was no clear difference observed between $\mathrm{MgAl}-\mathrm{LDH}_{00}$, and MgAl-LDH 220 . The adsorption of chromium on both adsorbents were increased to $11 \mathrm{mg} / \mathrm{g}$ when chromium concentration in the solution reaches $500 \mathrm{mg} / \mathrm{l}$. After increasing chromium concentration over $500 \mathrm{mg} / \mathrm{l}$, adsorption was decreased possibly due to desorption process that might be happened simultaneously. In the case of $\mathrm{MgAl}-\mathrm{LDH}_{450}$, adsorption capacity was dramatically increased until the chromium 


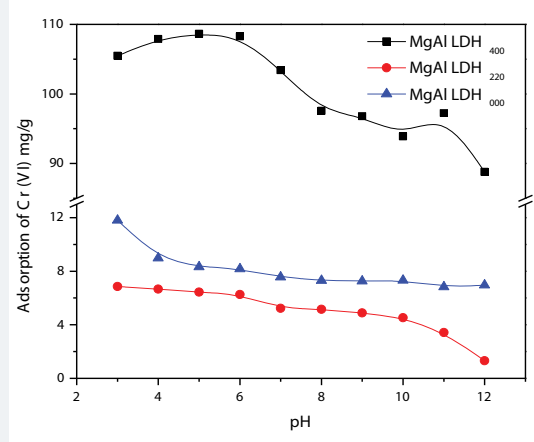

Figure 5: Chromium adsorption on MgAl-LDH ${ }_{000},{\mathrm{MgAl}-\mathrm{LDH}_{220} \text {, and MgAl-LDH }}_{450}$ with increasing $\mathrm{pH}$.

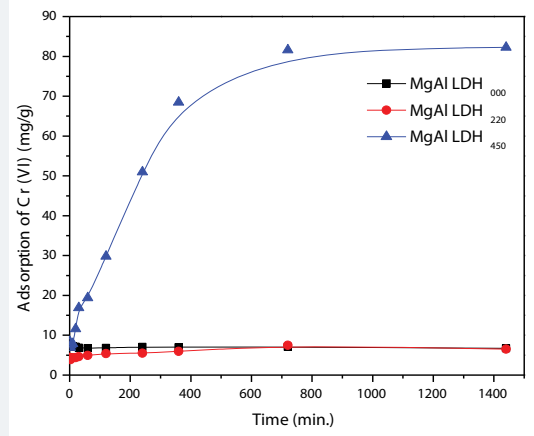

Figure 6: Effect of the MgAl-LDH ${ }_{000}, \mathrm{MgAl}^{-\mathrm{LDH}_{22}}$, and $\mathrm{MgAl}-\mathrm{LDH}_{450}$ on the adsorption kinetics of $\mathrm{Cr}(\mathrm{VI})$.

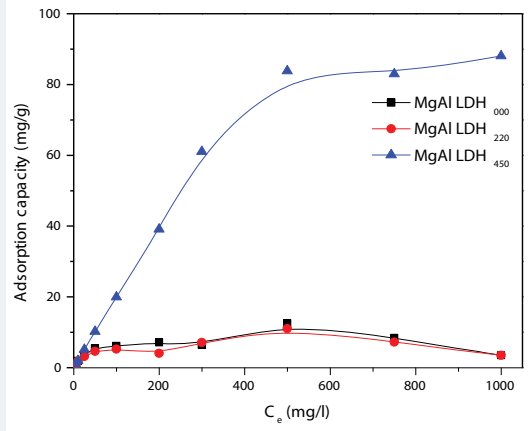

Figure 7: Adsorption capacities of $\mathrm{MgAl}-\mathrm{LDH}_{000}, \mathrm{MgAl}^{-\mathrm{LDH}_{220}}$, and $\mathrm{MgAl}-\mathrm{LDH}_{450}$ depending on chromium concentration in solution.

concentration in the solution reached to $500 \mathrm{mg} / \mathrm{l}$. Thus, the equilibrium was taken place even the concentration increased to $1000 \mathrm{mg} / \mathrm{l}$. The total capacities of MgAl$\mathrm{LDH}_{000}, \mathrm{MgAl}-\mathrm{LDH}_{220}$, and MgAl-LDH ${ }_{450}$ are $12.56 \mathrm{mg} / \mathrm{g}, 11.01 \mathrm{mg} / \mathrm{g}$, and $88.07 \mathrm{mg} / \mathrm{g}$, respectively.

The certain changes in structures of the three adsorbents were occurred after chromium adsorption. Figure 8 represents XRD patterns of the three adsorbents and chromium adsorbed on. There is almost no difference between Figure 8(a) and Figure 8(b). A broad sharp peak of MgAl- $\mathrm{LDH}_{220}$ on $15.22^{\circ}$ was shifted to $12.94^{\circ}$ and this peak was exactly overlapped on (003) reflection plane of MgAl-LDH. Thus, all the XRD peaks of $\mathrm{MgAl}-\mathrm{LDH}_{220}$ with $\mathrm{Cr}$ were fitted to the peaks of $\mathrm{MgAl}-\mathrm{LDH}_{000}$. It revealed that the thermally treated $\mathrm{MgAl}-\mathrm{LDH}$ at $220^{\circ} \mathrm{C}$ was destructed and dehydrated of its structure 


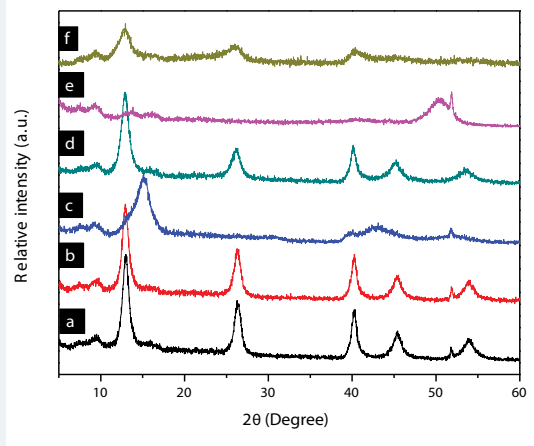

Figure 8: XRD patterns of (a) MgAl-LDH ${ }_{000^{\prime}}$ (b) MgAl-LDH ${ }_{000}$ with $\mathrm{Cr}$, (c) MgAl-LDH ${ }_{220^{\prime}}$ (d) MgAl-LDH 220 with $\mathrm{Cr}$, (e) ${\mathrm{MgAl}-\mathrm{LDH}_{450}}_{4}$ (f) $\mathrm{MgAl}^{-\mathrm{LDH}_{450}}$ with $\mathrm{Cr}$.

at some certain degree. The memory effect of MgAl-LDH was strong to reconstruct the basic structure when it was dipped in solution and no matter how much oxyanion in the solution. In the case of $\mathrm{MgAl}-\mathrm{LDH}_{450}$ with $\mathrm{Cr}$, memory effect was affected to create the original structure of MgAl-LDH. Carbonates and hydroxyl groups of $\mathrm{MgAl}-\mathrm{LDH}_{450}$ were lost in main structure. Therefore, reconstruction of $\mathrm{MgAl}-\mathrm{LDH}_{450}$ was not that good, although, some peaks arisen up on XRD pattern of the $\mathrm{MgAl}^{-\mathrm{LDH}_{450}}$ with $\mathrm{Cr}$ at degrees of $13.04^{\circ}, 26.1^{\circ}$, and $40.46^{\circ}$, which represented rearranged crystals of MgAlLDH.

The present research indicates that the thermal treatment of MgAl-LDH at certain temperatures can be improved the chromium adsorption from the aqueous solution up to 8 times.

\section{CONCLUSION}

MgAl-LDH was synthesized by simple co-precipitation method. The synthesis of hydrocalcite like compound was confirmed by XRD. The morphology of the MgAl-LDH was identified with SEM-EDX and represents homogenously distributed nano particles. The thickness of synthesized MgAl-LDH was around 20-30 nm. Thermal treatment of MgAl-LDH was performed at $220^{\circ} \mathrm{C}$, and $450^{\circ} \mathrm{C}$ and it represents partially decomposed structure. The adsorption capacities of $\mathrm{MgAl}-\mathrm{LDH}_{000}, \mathrm{MgAl}-\mathrm{LDH}_{220}$, and $\mathrm{MgAl}-\mathrm{LDH}_{450}$ were $12.56 \mathrm{mg} / \mathrm{g}, 11.01 \mathrm{mg} / \mathrm{g}$, and $88.07 \mathrm{mg} / \mathrm{g}$ at $\mathrm{pH}$ 7, respectively. Memory effect was still in $\mathrm{MgAl}-\mathrm{LDH}_{450}$ sample, although, $\mathrm{MgAl}-\mathrm{LDH}$ was deeply destructed to amorphous nano material such as MgAl double oxide.

\section{REFERENCES}

1. Sarkar M, Rahman AKML, Bhoumik NC. Remediation of chromium and copper on water hyacinth (E. crassipes) shoot powder. Water Resources and Industry. 2017; 17: 1-6. Ref.: https://goo.gl/tD3|3n

2. Rathnayake SI, Martens WN, Xi Y, Frost RL, Ayoko GA. Remediation of $\mathrm{Cr}(\mathrm{VI})$ by inorganic-organic clay. J Colloid Interface Sci. 2017; 490: 163-173. Ref.: https://goo.gl/J4czGz

3. WHO. Guidelines for Drinking-water Quality. In. WHO Press Switzerland 2006.

4. Goyer MAM. Advances in Modern Toxicology: Toxicology of Trace Elements. John Wiley \& Sons. New York. 2: 1977.

5. Saha R, Nandi R, Saha B. Sources and toxicity of hexavalent chromium. Journal of Coordination Chemistry 2011; 64: 1782-1806. Ref.: https://goo.gl/TXVVdm

6. Saha B, Orvig C. Biosorbents for hexavalent chromium elimination from industrial and municipal effluents. Coordination Chemistry Reviews. 2010; 254: 2959-2972. Ref.: https://goo.gl/RBCx4n

7. Zou Y, Wang X, Wu F, Yu S, Hu Y, et al. Controllable Synthesis of Ca-Mg-Al Layered Double Hydroxides and Calcined Layered Double Oxides for the Efficient Removal of U(VI) from Wastewater Solutions. ACS Sustainable Chemistry \& Engineering. 2016; 5: 1173-1185. Ref.: https://goo.gl/WSj7uz 
8. Khitous M, Salem Z, Halliche D. Effect of interlayer anions on chromium removal using Mg-A layered double hydroxides: Kinetic, equilibrium and thermodynamic studies. Chinese Journal of Chemical Engineering. 2016; 24: 433-445. Ref.: https://goo.gl/qM21tA

9. Wang $\mathrm{S}$, Gao B, Li Y, Zimmerman AR, Cao X. Sorption of arsenic onto Ni/Fe layered double hydroxide (LDH)-biochar composites. RSC Advances. 2016; 6: 17792-17799. Ref.: https://goo.gl/sQEroZ

10. Everaert M, Warrinnier R, Baken S, Gustafsson JP, Vos DD, et al. Phosphate-Exchanged Mg-Al Layered Double Hydroxides: A New Slow Release Phosphate Fertilizer. ACS Sustainable Chemistry \& Engineering. 2016; 4: 4280-4287. Ref.: https://goo.gl/Ba2NZ3

11. Zhang T, Li Q, Xiao H, Lu H, Zhou Y. Synthesis of Li-Al Layered Double Hydroxides (LDHs) for Efficient Fluoride Removal. Industrial \& Engineering Chemistry Research. 2012; 51: 11490-11498. Ref.: https://goo.gl/GoWiHm

12. Ferreiraa OP, Alvesa OL, Gouveiab DX, Souza Filhob AG, de Paiva JAC, et al. Thermal decomposition and structural reconstruction effect on Mg-Fe-based hydrotalcite compounds. Journal of Solid State Chemistry. 2004; 177: 3058-3069. Ref.: https://goo.gl/nYy526

13. Klemkaite K, Prosycevas I, Taraskevicius R, Khinsky A, Kareiva A. Synthesis and characterization of layered double hydroxides with different cations ( $\mathrm{Mg}, \mathrm{Co}, \mathrm{Ni}, \mathrm{Al})$, decomposition and reformation of mixed metal oxides to layered structures. Central European Journal of Chemistry. 2011; 9: 275-282. Ref.: https://goo.gl/1tt917

14. Zhou J, Su Y, Zhang J, Xu X, Zhao J, et al. Distribution of $\mathrm{OH}$ bond to metal-oxide in $\mathrm{Mg} 3-\mathrm{xCaxFe}-$ layered double hydroxide $(x=0-1.5)$ : Its role in adsorption of selenate and chromate. Chemical Engineering Journal. 2015; 262: 383-389. Ref.: https://goo.gl/5b8euu

15. Xu ZP, Zhang J, Adebajoa MO, Zhangc H, Zhou C. Catalytic applications of layered double hydroxides and derivatives. Applied Clay Science. 2011; 53: 139-150. Ref.: https://goo.gl/7N5j4l

16. Koilraj $P$, Srinivasan K. High Sorptive Removal of Borate from Aqueous Solution Using Calcined ZnAl Layered Double Hydroxides. Industrial \& Engineering Chemistry Research. 2011; 50: 69436951. Ref.: https://goo.gl/ZpTjfR 